KS. JERZY WOLNY

\title{
LISTA OBRAZÓW W KOŚCIELE PARAFIALNYM W SIEMONI Z DRUGIEJ POLOWY XVII WIEKU
}

Bernard Maciejowski biskup krakowski (1600-1606) ogłosił w $1601 \mathrm{r}$. list pasterski (Epistola pastoralis) zwany Pastoralna, który przeznaczony był dla duchowieństwa diecezji krakowskiej. Na synodzie prowincjonalnym w Piotrkowie w 1607 r. Maciejowski, wówczas kardynał, arcybiskup gnieźnieński i prymas Polski, nakazał biskupom diecezjalnym wprowadzić Pastoralna jako podręcznik duszpasterski w diecezjach polskich. Pastoralna Maciejowskiego, ułożona na podstawie uchwał soboru trydenckiego oraz konstytucji papieskich, z uwzględnieniem zbioru Karnkowskiego z 1578 r. miała ułatwić przeprowadzenie odnowy życia religijnego i kościelnego w Kościele polskim ${ }^{1}$.

W Pastoralnej, biskup polecał m.in. sporządzić w każdej parafii inwentarz (inventarium), w którym należało zestawić wszystkie potrzebne do kultu przedmioty znajdujące się w kościele, opisać dokladnie uposażenie, budynki, majątek ruchomy i nieruchomy oraz wyszczególnić wszelkiego rodzaju dochody i ofiary. Dokument ten należało sporządzić w trzech egzemplarzach, z których dwa miano zachować w parafii - jeden dla plebana, drugi pod opieka witrikusów - trzeci zaś przekazać biskupowi².

Dwa egzemplarze takiego inwentarza zachowały się w parafii Siemonia ${ }^{3}$. Inwentarze siemońskie były spisywane przez ks. Szymona Staniewicza i ple-

${ }^{1}$ Epistola Pastoralis ... Anno D. MDCVII; M. Jabloński, Teoria duszpasterstwa (wiek XVI-XVIII). W: Dzieje teologii katolickiej w Polsce. T. 2, cz. 1. Teologia humanistyczna. Pod red. M. Rechowicza. Lublin 1975, s. 336-339; A. Petrani, Kanonistyka. W: Dzieje teologii katolickiej w Polsce. T. 1. Średniowiecze. Pod. red. M. Rechowicza. Lublin 1974, s. 388 .

${ }^{2}$ Epistola Pastoralis, B 2.

${ }^{3}$ Parafia Siemonia zostala erygowana w r. 1225 przez biskupa krakowskiego Iwona Odrowąża. Do rozbiorów należała do dekanatu bytomsko-siewierskiego diecezji krakowskiej; graniczyła z parafią św. Małgorzaty w Bytomiu do r. 1277, kiedy powstała parafia 
bana Siemoni ks. Franciszka Bernarda Petrycego, który objął parafię w dniu 30 czerwca 1659 r. w niedziele Trójcy Przenajświętszej, wprowadzony przez Wawrzyńca Kłobuckiego, plebana sąsiedniej parafii Sączów ${ }^{4}$. Ks. Franciszek Bernard Petrycy (zm. 1690) pochodził ze znakomitej rodziny uczonych.

Jego dziad mianowicie Sebastian Petrycy z Pilzna (1554-1627), był wybitnym znawca filozofii Arystotelesa, którego kilka dziel przełożył na język polski, był więc pierwszym filozofem piszącym po polsku, czym przyczynił się do powstania i rozwoju polskiej terminologii filozoficznej. Studia na Uniwersytecie Krakowskim rozpoczał w 1573 r.; w następnym roku uzyskal stopień bakalarza sztuk wyzwolonych. $Z$ nieznanych przyczyn przerwal jednak studia i zacząl pracować jako nauczyciel w Olkuszu. W 1583 r. za pierwszą lokatę egzaminacyjna otrzymal tytul magistra sztuk wyzwolonych. Odtąd rozpoczęla się jego szybka kariera uniwersytecka. W 1584 otrzymal katedre poetyki, w 1588 r. katedrę retoryki, zyskując sławę świetnego wykładowcy. Za gorliwe wypełnianie obowiązków uniwersytet udzielił mu dwuletniego urlopu na wyjazd do Italii. Tam w Padwie studiował medycynę. $Z$ wyróżnieniem złożył rygorozum na wydziale medycznym. Równocześnie $\mathrm{z}$ medycyną studiował interesująca go zawsze filozofię. Do kraju powrócil w połowie $1590 \mathrm{r}$. i rozpocząl wykłady z filozofii Arystotelesa. Zabiegał o nostryfikacje swego dyplomu doktora medycyny. Inkorporację do Wydziału Lekarskiego uzyskał dopiero w 1603 roku. Nadzwyczajne prelekcje medyczne głosił w semestrze zimowym 1608/9. W 1603 r. objąl stanowisko przybocznego lekarza bpa Maciejowskiego, swojego mecenasa oraz kilku wybitnych osobistości spośród małopolskich dygnitarzy. W latach 1606-7 przebywał w Księstwie Moskiewskim, gdzie uczestniczył w uroczystościach z okazji ślubu Maryny Mniszchówny z Dymitrem Samozwańcem i gdzie nieomal nie postradal życia; przez pewien czas był więziony. Dzięki praktyce lekarskiej dorobil się znacznej fortuny i zgromadził bogatą bibliotekę. Uniwersytetowi zapisal 6 tysięcy złp., zaś dochód od tej sumy przeznaczył na podniesienie pensji profesorów oraz na stypendia dla biednych studentów z Pilzna. W opinii wspólczesnych uchodził za orędownika stanu plebejskiego. Dla Uniwersytetu zasłużył się wielce fundacją (12 V 1620) stanowiska stałego historiografa, który był obowiazany do spisywania ważniejszych wydarzeń związanych $\mathrm{z}$ uczelnią mających miejsce $\mathrm{w}$ Polsce i za granicą ${ }^{5}$.

w Kamieniu nad Brynica, (miejsce urodzenia biskupa krakowskiego Nankera). Od północy graniczyla z parafią Sączów, erygowaną w r. 1224 przez Iwona Odrowąża. Do parafii Siemonia należały wsie: Siemonia, Rogoźnik, Dobieszowice, Twardowice, Strzyżowice, Góra Siewierska, Brzękowice. - Zbiór dokumentów malopolskich z lat 1211-1400. Wydali S. Kuraś i J. Sulkowska. Cz. IV dokumenty. Wroclaw 1969 nr 871, s. 4-7.

${ }^{4}$ Inventarium I k. 2-2 v., k. 3.

${ }^{5}$ H. Barycz, Petrycy Sebastian z Pilzna (1554-1627). W: PSB, t. 25, s. 703-707. 
Najstarszy syn Sebastiana, Jan Innocenty Petrycy (1592-1641), poszedł w ślady ojca. Wraz z bratem Gabrielem wpisał się do metryki Uniwersytetu Krakowskiego (2 IX 1605); prawdopodobnie w Krakowie uzyskal jedynie bakalaureat sztuk wyzwolonych. Na doktorat $z$ filozofii i medycyny promował się na uniwersytecie bolońskim (19 VII 1618), gdzie prawdopodobnie od 1616 r. odbywal studia lekarskie. Po powrocie do kraju został inkorporowany do fakultetu (10 IV 1620), ale nie podjałł wykładów z zakresu medycyny, ponieważ w roku następnym otrzymał fundowane przez ojca stanowisko historiografa Akademii Krakowskiej. Do godności historiografa uniwersyteckiego dołaczył Jan Innocenty obowiazki profesora wymowy na katedrze retoryki, erygowanej przez bpa krakowskiego Piotra Tylickiego (1616). W polemice $z$ jezuitami stanał w obronie praw Akademii i podpisał antyjezuicką deklarację profesorów krakowskich w 1632 r. Praktyka lekarska, pacjenci z magnaterii, bogate ożenki pomnożyly majatek, jaki Jan Innocenty otrzymał po śmierci swojego ojca Sebastiana.

Jako jedyny spadkobierca odziedziczył po swym ojcu kamienice przy ulicy św. Jana w Krakowie, folwark Olsza na Prąniku pod Krakowem, wieś Siemonię w Księstwie Siewierskim, kolekcję obrazów, księgozbiór, cenne kosztowności i sporą sumę pieniędzy. Rodzina dwukrotnie żonatego Jana Innocentego liczyła pięć córek: Anna (pierwsza żona Hieronima Ardentiego, pisarza żup wielickich), Katarzyna (żona. bogatego kupca krakowskiego Adriana Horlemesa), Teofila (zakonnica klasztoru karmelitanek pod imieniem św. Teresy we Lwowie), Teresa (zakonnica klasztoru norbertanek na Zwierzyńcu w Krakowie, gdzie pełniła obowiązki kronikarki i bibliotekarki konwentu) i Barbara, oraz trzech synów: Szymon, Jan Aleksander i Franciszek Bernard ${ }^{6}$.

Najmłodszy z rodzeństwa, Franciszek Bernard, studiowal w Akademii Krakowskiej; bakałarza artium zdobyl w 1649 r., magistra artium w 1652 r. Jako docent extraeneus wykladal na Wydziale filozoficznym w latach 1652/3. Nie wiadomo kiedy uzyskał doktorat obojga praw ${ }^{7}$. Na tym Franciszek zakończy karierę naukową i wybrał stan duchowny. Pierwszym stanowiskiem kościelnym jakie otrzymał, była prebenda Bractwa Miłosierdzia przy kościele Mariackim w Krakowie. Prace w duszpasterstwie parafialnym rozpoczał jako wikariusz w parafii Repty koło Tarnowskich Gór na Górnym Śląsku i w tejże parafii został później plebanem. Po rezygnacji z parafii siemońskiej Ks. Sta-

${ }^{6}$ L. Hajdukiewicz, Petrycy Jan Innocenty (1592-1641). W: PSB. T. 25, s. 701-703; Renata Zurkowa, Z dziejów biblioteki Jana Innocentego Petrycego, „Roczniki Biblioteki Polskiej Akademii Nauk w Krakowie" t. 14:1968 s. 43-63; L. Hajdukiewicz, Petrycy..., s. 703.

${ }^{7}$ L. Hajdukiewicz, Petrycy Jan Innocenty. W: Slownik pracowników ksiażki polskiej. Suplement, Warszawa 1985, s. 166. 
nisław Rapa, doktora obojga praw, kanonika wiślickiego i prepozyta siewierskiego, właściciele podzielonej między siebie Siemoni, rodzeństwo Jan, Szymon i Katarzyna, patroni i kolatorzy parafii siemońskiej prezentowali na plebana swojego brata, ks. Franciszka Bernarda Petrycego ${ }^{8}$.

Właśnie jako pleban parafii siemońskiej ks. Franciszek Bernard Petrycy przyczynił się do sporzadzenia inwentarza tejże parafii. Na podstawie tego dokumentu poznajemy m.in. historię samego kościoła oraz uzyskujemy szczególowe przedstawienie wszystkiego, co się w nim mieścilo. Do szczególnie zajmujących należy informacja o znajdującej się w kościele bogatej kolekcji obrazów, którą w oryginalnej pisowni poniżej przytaczam. Informacja ta jest tym cenniejsza, że niestety do naszych czasów nie zachowal się żaden z ujętych w inwentarzu obrazów.

\section{OBRAZY}

[1] Obrazÿ dwa iednakowe na descze staroswiecką robotą malowane, podługowate, na jednym wprowadzenie do Raiu, na drugim wÿprowadzenie e Limbo przez Christusa Pana.

[2] Obraz szeroki ÿ wielki S. Annÿ z Genealogią Nas: Pannei, staroswieckim malowaniem na descze.

[3] Obraz Crucifixi na descze staroswiecką robotą malowanÿ, na ktorym Genealogia PP. Rogoiskich z Herbami ichze.

[4] Obraz Crucifixi na plotnie w ramach malowanÿ, pod Krucifixem klęczący W. X. Walanty Nicocius Pleban tegosz koscioła.

[5] Obrazÿ dwa na desczkach podlugowatych staroswiecką robotą malowane, na iednym z nich Nas. Panna, na drugim Anioł zwiastuiącÿ.

[6] Obraz S. Woiciecha mały na Plotnie w Ramach malowanÿ; od W. X. Woiciecha Jeneczkowica Commendarza Sięmonskiego Kosciołowi darowanÿ.

[7] Obraz w wielkim chorze z spręglami rzerzanemi, Nas: Pannei bolesnei, pod ktorym Rod Woiciecha Cyrana z Epitaphium, na murze przybitÿ.

[8] Obraz Nas: Pannei Czestochowskiei, na plotnie w ramach prostą robota malowanÿ.

[9] Obraz drugi Nas: Pannei Czestochowskiei takisz.

[10] Obrazek maly Annunciationis B. Marię moskiewskiej robotÿ malowania nad szafeczka, gdzie olea sacra, przÿbÿtÿ.

[11] Oltarzyk maly snecerską robotą robiony, ktorÿ stawa na Tafli u ołtarza Nas: Pannÿ.

[12] Crucifix rzerzanÿ na srodku Koscioła pod Framugą przÿbitÿ, wielki.

${ }^{8}$ Inventarium I, f. $1 \mathrm{r}-2 \mathrm{v}$; Inventarium II, k. 1-3. 
[13] Crucifix mnieiszÿ, na Listwie w bok wielkiego ołtarza zawieszonÿ, ktorÿ się zazywa na Wielki piątek.

[14] Crucifix mały nad Cinborium na wielkim oltarzu, snecerskim rzerzaniem.

[15] Crucifix mały na oltarzu Nas: Pannei prostym rzerzaniem.

[16] Crucifix na ołtarzu S. Annei.

[17) Crucifix nad szafka gdzie olea sacra. tei.

[18] Crucifix w Zakristiei nad Szafami gdzie się ubieraią do Mszÿ Swię-

[19] Krzysz mały drewnianÿ, złotem malarskim ÿ farbami pomalowanÿ, w ktorym iest Agnus Dei, sprawionÿ ÿ Kosciolowi darowanÿ od Slachetnei P. Zophiei Nawalskiei die 4 Juny w Roku 1672.

[20] Obraz Quatuor nouissimorum, na plotnie pod wode malowanÿ, w wielkim Chorze pod oknami przybity, sprawionÿ od X. Franciszka Petricego Plebana Sięmonskiego die 10 April w Roku 1673.

[21 ) Krzysz drewnianÿ prostÿ, malarskim srebrem pomalowanÿ; w ktorym iest Agnus Dei, dla częstego uzywania ÿ ochrony srebrnego Krzyza sprawionÿ od Xiedza Franciszka Petricego Plebana Sięmonskiego die 18 Juny w Roku 1673.

[22) Krucifix drewnianÿ wielki po bok na scienie miedzy Oltarzem Wielkim a formami i po lewej stronie na Listwie wiszący sprawiony od W. X. Franciszka Petricego Plebana Sięmonskiego die 30 April. A. 1678.

[23] Obraz Naswietszei Panny P. Jezusa trzymaiacei na plotnie malowanÿ, darowanÿ $\ddot{y}$ ofiarowany kosciołowi Sięmonskiemu od Slachetnei P. Zophiei Nawalskiei w Roku 1676.

[24] Obraz Smierci z kosą obszernÿ, ktory się wystawia na wielki oltarz, podczasz Pogrzebow slacheckich znacznych y na dzien zadusznÿ, sprawiony od W. X. Franciszka Petricego Plebana Sięmonskiego w Roku 1679 die $1 \mathrm{Julÿ}$.

Do obrazów nie wspomnianych w powyższej liście, należy najważniejszy, przedstawiający Najświętszą Marię Pannę, wykonany „starą robota” (vetusto opere), prawdopodobnie z okresu średniowiecza, cieszył się szczególnym kultem wśród parafian, jak poświadczają o tym liczne wota ${ }^{10}$. W oltarzu głównym, drewnianym, fundowanym $\mathrm{w}$ roku 1469 , odnowionym w roku 1612, scena przedstawia koronację Najświętszej Maryi Panny przez Trójcę Świętą. Ten ołtarz ofiarował kościołowi siemońskiemu w roku 1632 prepozyt Bożego

\footnotetext{
9 Lista obrazów znajduje się w Inventarium I, k. 91-91v.

${ }^{10}$ Inventarium I, k. 5.
} 
Ciała na Kazimierzu w Krakowie, Marcin Kłoczyński, ważna postać, należąca do najbliższego otaczenia bpa Piotra Gembickiego ${ }^{11}$.

Petrycy często wspomina różne prace przy odnawianiu kościoła. Poznajemy z jego relacji tylko jednego malarza, był nim (honestus) Stanisław Ligencki (Ligęcki) z Tarnowskich Gór. Spod jego pędzla wyszło kilka obrazów dla kościoła siemońskiego, zamawianych przez ks. Petrycego ${ }^{12}$.

${ }^{11}$ Inventarium $I I, \mathrm{k} .6 \mathrm{v}-7$; H. W. Wyczawski, Biskup Piotr Gembicki 1585-1657. Kraków 1957, s. 60-61, 251.

${ }^{12}$ Inventarium $I I, \mathrm{k} .8$. 